\title{
MAKALAH \\ MENYEMAI TOLERANSI DI BUMI PERTIWI
}

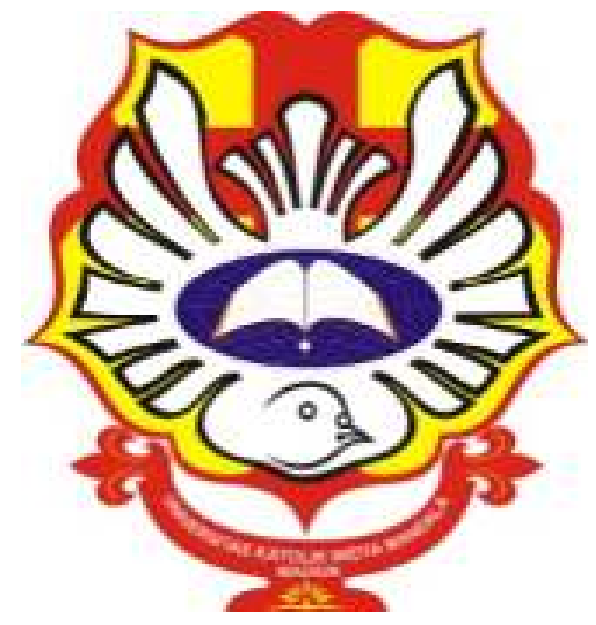

Alfriza Divra Rizky Rezaldy

NIM. 3903019002

UNIVERSITAS KATOLIK WIDYA MANDALA MADIUN

TAHUN 2019 


\title{
Menyemai Toleransi di Bumi Pertiwi
}

\author{
Alfriza Divra Rizky Rezaldy
}

\begin{abstract}
Abstrak
Simpul persatuan Indonesia mulai lepas ketika intoleransi berkembang. Isu - isu yang berupa hoax, intimidasi, dan persekusi dihembuskan ke masyarakat. Akibatnya terjadi gesekan antar elemen bangsa yang menyebabkan memudarnya rasa toleransi sebagai sesama anak negeri. Intoleransi ini yang terus dibakar dengan isu hoax dan penyesatan pikiran sehingga menjadi radikalisme. Negara dianggap musuh karena seakan - akan mengintimidasi dan mengesampikan salah satu agama. Banyak aksi teror yang terjadi karena radikalisme yang disebabkan intoleransi ini. Teror bom bunuh diri ditengah masyarakat, pemerintah ditekan dengan demonstrasi, aparat kepolisian diserang menjadi lebih sering terjadi belakangan ini. Karena hilangnya rasa toleransi menyebabkan rentetan masalah baru yang semakin pelik. Kini saatnya kembali menyemai toleransi di bumi pertiwi.
\end{abstract}

Kata kunci

toleransi, gotong - royong, Indonesia

\section{A. Pendahuluan}

Bangsa Indonesia di masa kini menghadapi malasah utama dan besar yang juga mengancam kelangsungan hidup negara Indonesia yaitu intoleransi. Rasa intoleran muncul di berbagai lini kehidupan masyarakat mulai dari daerah, suku, budaya, dan yang terbesar adalah politik dan agama. Intoleransi tumbuh subur belakangan ini karena sengaja dibakar untuk komoditas politik supaya meraup kursi kekuasaan. Isu agama digoreng sedemikian rupa hingga masyarakat antar umat beragama seakan - akan saling berhadapan dan memicu ketegangan di beberapa lini kehidupan lainnya.

Agama digunakan sebagai untuk berkuasa, namun tidak digunakan secara bijak. Yang seharusnya digunakan sebagai dasar perjuangan politik, agama malah digunakan untuk senjata agar masyarakat takut dan saling bertikai. Akibatnya tumbuh rasa sinisme dengan identitas agama sehingga timbulah rasa intoleran. Masalah ini semakin pelik karena meluas ke ranah kedaerahan, kesukuan, kebudayaan. 
Akibat dari berkembangnya rasa intoleransi ini, ada harga yang harus dibayar mahal oleh bangsa Indonesia yaitu retaknya persatuan nasional yang telah dirajut sejak dulu. Simpul - simpul persatuan yang dirajut sekian lama harus lepas dan butuh dirajut kembali seperti sediakala sehingga tercipta keharmonisan dalam masyarakat.

\section{B. Latar belakang}

Gesekan antar umat beragama yang terlihat signifikan dan menjadi isu nasional bermula saat perhelatan Pemilihan Gubernur DKI Jakarta Tahun 2017. Saat itu untuk meraih kursi kekuasaan, isu agama dimainkan begitu hebatnya hingga menyentuh ke lapisan masyarakat terendah. Masyarakat didoktrin untuk tidak memilih salah satu Calon Gubernur karena tidak seiman atau seagama, yang sebenarnya tidak ada ketentuan perundang undangan yang mengatur tentang hal tersebut. Isu lain yang dihembuskan dan akhirnya benar - benar dilakukan adalah jika seseorang dari satu umat memilih Calon Gubernur dari yang tidak seiman tidak akan diurus jenazahnya jika meninggal dunia.

Isu - isu yang dihembuskan semakin kuat karena dimotori oleh beberapa ormas keagamaan yang memang kurang setuju dengan konsep kenegaraan Indonesia karena dianggapnya tidak sesuai dengan ajaran agama. Ormas keagamaan ini berkeinginan menghadirkan kembali ajaran agama tertentu di tengah masyarakat. Dalam mewujudkan keinginan tersebut mereka menggunakan pengerahan massa turun kejalan, mengintimidasi masyarakat, mengancam pemerintah, dan melawan penegak hukum. Cara ini acap kali menggunakan kekerasan dan persekusi.

Antar masyarakat dikondisikan untuk bermusuhan karena perbedaan pendapat yang semakin meruncing. Penafsiran ajaran agama yang salah dan penyesatan logika berpikir membuat benturan di masyarakat. Dari yang sebelumnya masyarakat bersatu menjadi terpecah. Antar tetangga menjadi tidak rukun, saudara yang seiman menjadi bermusuhan, saudara yang tidak seiman dilabeli kafir.

Semua terjadi berlarut - larut hingga sekarang dan berdampak besar bagi kehidupan berbangsa dan bernegara. Intoleransi kini naik satu tingkat pada level radikalisme. Dewasa ini frekuensi aksi teror lebih sering terjadi daripada saat sebelum Pemilihan Gubernur DKI Tahun 2017. Karena ketatnya persaingan politik di kontestasi ini, membuat seluruh tenaga yang dikerahkan menjadi besar. Pendukung juga dikerahkan dan terjadilah sentimen yang buta, menganggap perbedaan pilihan politik sebagai musuh yang harus dibasmi. Rasa 
sentimen ini menjadi lebih kuat saat dipupuk dengan ajaran agama yang salah dalam memahami konteks penafsirannya. Maka jadilah seperti sekarang, pemikiran radikal semakin tumbuh dan aksi terorisme merebak di penjuru negeri.

\section{Pembahasan}

Sejak zaman dahulu para perintis, pejuang, dan pahlawan kemerdekaan menyadari bahwa masyarakat nusantara sangat majemuk dan negara Indonesia merdeka tidak bisa terwujud jika kemajemukan itu tidak bersatu. Sangat sulit mempersatukan masyarakat yang berbeda pulau, suku, kebudayaa, ras, dan agama. Ini menjadi tantangan besar bagi para tokoh dalam perjuangannya. Perbedaan yang paling besar adalah keyakinan agama, ada puluhan agama dan kepercayaan yang ada di bumi nusantara, dan perlu adanya jalan tengah untuk persatuan bangsa. Para tokoh pemuka agama berjuang bersama - sama menyatukan tujuan yaitu Indonesia merdeka.

Indonesia didirikan oleh Para Pendiri Bangsa bukan sebagai negara agama namun sebagai negara beragama. Negara ini tidak menganut salah satu ajaran yang ada melainkan berlandaskan dari nilai - nilai umum semua agama. Para Pendiri Bangsa telah merancang sedemikian rupa bagaimana agar negara Indonesia kokoh bersatu dengan keragaman yang ada. Sudah sangat tepat jika negara Indonesia tidak menjadi negara agama dan tidak menjadi negara sekuler tetapi menjadi negara beragama. Karena akan mengakomodasi semua kepentingan umat beragama yang ada didalamnya dan tidak menciderai semangat kebersamaan yang selama ini telah terjalin.

Kehidupan masyarakat Indonesia tidak akan lepas dari ajaran agama karena agama menjadi dasar kehidupan masyarakat Indonesia. Maka sangat wajar jika partai politik banyak yang menggunakan agama sebagai landasan perjuangan politiknya. Hal ini sudah nampak sejak negara berdiri. Ada partai politik yang berbasis nasionalis dan berbasis agamis. Dewasa ini partai politik nampak terafiliasi pada kedua basis tersebut. Sayangnya, partai politik yang melabeli diri sebagai partai agama dekat dengan organisasi masyarakat keagamaan yang dinilai radikal dalam memperjuangkan kepentingan.

Dalam memperjuangkan kepentingannya organisasi masyarakat keagamaan ini berdalih hanya memperjuangkan kepentingan umat, namun nyatanya dalam realisasi seluruh acara ditunggangi oleh kepentingan politik. Aksi unjuk rasa menjadi jurus andalan karena 
dianggap sebagai representasi kehendak masyarakat umum. Padahal demonstrasi belum tentu mewakili keseluruhan suara rakyat.

Pada saat Pemilihan Gubernur DKI Jakarta Tahun 2017 segala cara dihalalkan untuk dua tujuan penjegalan salah satu calon yaitu kalah suara dalam pemilihan atau dipidanakan oleh pengadilan. Cara - cara yang digunakan terlalu keterlaluan karena sudah bersifat provokatif, memfitnah, dan mengancam. Demo besar - besaran menuntut untuk dipidana karena dianggap menistakan agama. Isu - isu yang menyesatkan digoreng untuk meraih kemenangan.

Banyak isu yyang dimainkan selama kontestasi pilkada. Masyarakat didoktrin untuk tidak memilih calon tersebut karena tidak seiman dan dilabeli kafir, yang sebenarnya kata kafir tidak relevan dengan keadaan dewasa ini. Seharusnya dalam memilih pemimpin hanya melihat kompetensi yang dimiliki, bukan karena hal lain yang tidak bersangkutan dengan menjalankan pemerintahan. Ada juga ancaman kepada masyarakat jika memilih calon tersebut tidak akan diurus jenazahnya ketika meninggal dunia, dan ini benar - benar dilakukan. Selama itu pula isu hoax diangkat untuk pembenaran kesalahan dan menyalahkan kebenaran. Belakangan terbongkar ada tim khusus untuk memproduksi dan distribusi hoax hoax yang bertujuan untuk menyesatkan masyarakat. Aksi persekusi antar pendukung marak terjadi karena hoax yang dihembuskan. Kesemua hal tersebut menciderai rasa kemanusiaan dan tidak sehat bagi demokrasi. Paling mengerikan adalah hilangnya rasa toleransi.

Akibat dari hoax yang dihembuskan membuat benturan di tengah masyarakat. Banyak orang yang termakan oleh berita bohong sehingga merasa dizalimi oleh negara. Karena isu yang tidak benar muncul rasa diperlakukan tidak adil oleh negara. Dari hal ini muncul rasa ingin berjuang yang berlanjut menjadi radikal. Radikalisme ini semakin berkembang karena dibakar oleh isu hoax dan penyesatan ajaran. Negara Indonesia dianggap bukan bentuk yang tepat karena tidak bisa mengakomodasi kepentingan umat terbesar. Mereka ingin mengganti pondasi dan bentuk negara republik dengan bentuk negara padang pasir dengan satu imam tunggal didunia. Rasa perjuangan ini berlanjut dengan melawan kepada aparat kepolisian karena dianggap sebagai alat negara yang menghalangi perjuangan mendirikan negara padang pasir. Aparat kepolisian dianggap musuh dan diserang. Saat kepolisian tak gentar menghadapi ancaman kelompok radikal, masyarakat yang diserang untuk menciptakan rasa takut dan mengacaukan situasi keamanan. Hal ini dilakukan agar tercipta presepsi bahwa negara gagal tidak dapat melindungi rakyatnya. 
Banyak aksi teror yang terjadi semenjak tahun 2017. Aksi teror yang paling mengejutkan publik adalah ketika tiga rumah ibadah, kantor polisi, dan rusunawa dibom dalam waktu yang bersamaan. Banyak korban jiwa yang berjatuhan. Motif bom bunuh diri disinyalir karena pelaku terpapar radikalisme. Radikalme ini sepertinya muncul dari rasa ketidakpercayaan dan ketidakadilan karena merasa umatnya tertindas oleh pemerintah. Padahal tidak demikian, pemerintah tidak pernah menindas salah satu umat agama tertentu. Pemerintah memperlakukan semua secara adil sesuai dengan kebutuhan dan proporsional. Anggapan mereka bahwa umat mayoritas dikesampingkan dan ditindas adalah salah besar karena pemerintah dalam menjalankan roda pemerintahan pasti memiliki peraturan perundangan yang mengatur tentang sesuatu hal.

Tidak semestinya salah satu agama dikesampingkan di negeri ini. Semua keperluan dan kepentingan telah diakomodasi negara. Mulai dari hari raya, tempat ibadah, acara perayaan, perjalanan ibadah semua komponen itu telah difasilitasi oleh negara. Sehingga tidak ada yang dianak-tirikan oleh pemerintah. Hal tersebut menjadi alasan kuat bahwa antar umat beragama harus rukun tidak saling bermusuhan tidak ada sentimen negatif diantara umat. Karena tidak ada yang diperdebatkan dalam menjalankan ajaran agamanya masing masing.

Untuk meraih kemerdekaan seluruh elemen bangsa bersatu tanpa memandang SARA. Semua bersatu mencapai tujuan bersama yaitu Indonesia merdeka. Saat negara berdiri juga sudah diberi pondasi yang kuat yaitu Pancasila, didalamnya terkandung lima dasar falsafah hidup bangsa. Soekarno kembali mencetuskan Pancasila yang lima ini menjadi satu perasan yang paling inti atau Ekasila yaitu gotong royong.

Gotong royong yang menjadi kunci utama masyarakat Indonesia yang telah ada sebelumnya dan dikristalisasi oleh Soekarno. Seperti yang diungkapkan oleh Dr. Agustinus Dewantara, S. S., M. Hum. Dalam bukunya Diskursus Filsafat Pancasila Dewasa Ini sebagai berikut:

"Suatu bangsa memiliki nilai - nilai tertentu sebagai ciri khasnya. Gotong royong secara historis merupakan budaya asli Indonesia yang telah dipraktikkan oleh leluhur bangsa mulai zaman kerajaan, penjajahan, merebut kemerdekaan, dan zaman awal kemerdekaan. Budaya ini terbukti memberi kontribusi yang besar bagi terwujudnya cita - cita bersama. Nilai gotong royong terefleksikan dalam filosofi bangsa yakni Pancasila.” 
Gotong royong adalah budaya asli Indonesia telah ada sejak zaman dahulu kala berkontribusi mewujudkan tujuan bersama. Gotong royong mengikut seluruh elemen yang ada dalam masyarakat. Pada masa kini gotong royong telah hilang berganti dengan radikalisme. Radikalisme tumbuh dari rasa intoleran, rasa intoleran tumbuh saat gotong royong terkikis. Masalah sudah jelas terlihat saat ini, yaitu hilangnya gotong royong yang ada dalam masyarakat. Masyarakat hendaknya mulai tersadar bahwa nilai gotong royong yang pernah ada perlu diadakan kembali untuk mengembalikan persatuan yang porak poranda karena perpecahan dan permusuhan.

Sebelum bersatu kembali seluruh masyarakat harus menyamakan persepsi tentang menghormati perbedaan satu sama lain dan membuat perbedaan menjadi kekuatan. Karena perbedaan yang ada masyarakat harus menumbuhkan kembali rasa toleransi. Toleransi akan menjadi lem perekat yang menyatukan kembali potongan - potongan yang terpecah hingga menjadi satu kesatuan. Benih toleransi harus disemai oleh semua pemimpin baik pemimpin pemerintahan, tokoh agama, pemuka adat, dan sebagainya. Benih ini yang akan tumbuh sedikit demi sedikit untuk menjadi besar dan kuat hingga toleransi tertancap dengan kokoh di dalam manusia Indonesia.

Toleransi yang akan menjadikan bersatu, bergotong royong dan akan menjadikan negara Indonesia hebat karena seluruh masyarakatnya manunggal nyawiji atau melebur bersatu seperti dalam filosofi Jawa.

\section{Penutup}

Toleransi harus dibumikan lagi ditengah masyarakat untuk mengembalikan yang sudah retah dan hilang dari negeri ini yaitu gotong royong. Jika kita telah menyemai kembali toleransi di bumi pertiwi yang kita cintai ini, masyarakat akan kembali bersatu bergotong royong dan menjadikan Indonesia yang hebat di mata internasional.

Butuh dukungan dari para pemimpin untuk menanamkan rasa toleransi kepada masyarakat. Masyarakat juga hendaknya mau menghormati perbedaan yang ada di negara Indonesia yang majemuk ini. Karena perbedaan yang membuat kita kuat. 


\section{DAFTAR PUSTAKA}

Dewantara, Agustinus W. 2017. Alangkah Hebatnya Negara Gotong Royong : Indonesia dalam Kacamata Soekarno. Yogyakarta : Kanisius.

Dewantara, Agustinus W. 2017. Diskursus Filsafat Pancasila Dewasa Ini. Yogyakarta: Kanisius. 